The Uneven Legal Push for Europe

Questioning Variation when National Courts go to Europe

Wind, Marlene; Martinsen, Dorte Sindbjerg; Rotger, Gabriel Pons

Published in:

European Union Politics

DOI:

$10.1177 / 1465116508099761$

Publication date:

2009

Document version

Early version, also known as pre-print

Citation for published version (APA):

Wind, M., Martinsen, D. S., \& Rotger, G. P. (2009). The Uneven Legal Push for Europe: Questioning Variation when National Courts go to Europe. European Union Politics, 10(1), 63-88.

https://doi.org/10.1177/1465116508099761 


\title{
European Union Politics
}

http://eup.sagepub.com

\section{The Uneven Legal Push for Europe: Questioning Variation when National Courts go to Europe}

Marlene Wind, Dorte Sindbjerg Martinsen and Gabriel Pons Rotger

European Union Politics 2009; 10; 63

DOI: $10.1177 / 1465116508099761$

The online version of this article can be found at:

http://eup.sagepub.com/cgi/content/abstract/10/1/63

\author{
Published by: \\ (4)SAGE \\ http://www.sagepublications.com
}

Additional services and information for European Union Politics can be found at:

Email Alerts: http://eup.sagepub.com/cgi/alerts

Subscriptions: http://eup.sagepub.com/subscriptions

Reprints: http://www.sagepub.com/journalsReprints.nav

Permissions: http://www.sagepub.co.uk/journalsPermissions.nav

Citations http://eup.sagepub.com/cgi/content/refs/10/1/63 


\section{EUP}

European Union Politics

DOI: 10.1177/1465116508099761

Volume 10 (1): 63-88

Copyright@ 2009

SAGE Publications

Los Angeles, London, New Delhi, Singapore and Washington DC

\section{KEY WORDS}

- causality

- legal integration

- majoritarian democracy

- national courts

\section{The Uneven Legal Push for}

\section{Europe}

\section{Questioning Variation when National Courts go to Europe}

\section{Marlene Wind}

University of Copenhagen, Denmark

\section{Dorte Sindbjerg Martinsen}

University of Copenhagen, Denmark

\section{Gabriel Pons Rotger}

Danish Institute of Governmental Research $(A K F)$, Denmark

\section{ABSTRACT}

National courts have been key players in the legal push for Europe, though notably to varying degrees. This paper examines the persisting variations in the referral rates of national courts and the underlying causal factors, aiming to better understand why some member states' courts have been more reluctant to join in the legal push for Europe. By using econometric methods, it challenges the modified neofunctionalist argument that the extent of intra-EC trade explains the referral practice of the individual member states. Majoritarian democracy is hypothesized as a causal factor in the low referral rates for some of the EU member states. Key characteristics of majoritarian democracy versus constitutional democracy are outlined and the former is further detailed by means of two case studies: Denmark and the UK. Finally, a panel data analysis is conducted and finds evidence of a negative impact of majoritarian democracy on the number of referrals. The paper concludes that, owing to the uneven legal push for Europe, some member states and their citizens remain at arms' length from the legal integration process - and, in consequence, from the full impact of European integration. 


\section{Introduction}

Judicial activity in the European Court of Justice (ECJ) continues to increase. Through the preliminary referral procedure and the willingness of national courts to bring cases to the ECJ, the legal and political content of the European Community has gradually, but fundamentally, been transformed. For quite some time already, the European integration process has been about much more than merely liberalizing trade and integrating markets. Sensitive national issues, including social and health policy, monetary policy and free movement rights for employed as well as unemployed persons, have become 'Europeanized' over the years (Martinsen, 2005; Martinsen and Vrangbæk, 2008; Wind, 2009 forthcoming). The ECJ has been one of the main engines driving this process.

Considered alone, however, the European Court is a rather weak institution. In order to influence the direction of the EU, the Court fundamentally depends on national courts and their willingness to bring cases forward. National courts thus constitute the crucial link between litigants and the ECJ, conditioning which questions will be brought to the ECJ and the specific content of such questions. As demonstrated below, however, the referral rates of national courts continue to vary considerably. Courts in some member states are much more reluctant to participate in the legal push for further integration. Such variation has more general implications because it suggests that, in some member states, individual citizens are confronted with greater thresholds that have to be overcome when approaching the European Union than occurs in other member states. The puzzle of this paper is why national courts in some member states have been more reluctant to bring cases to the ECJ and have therefore not joined the legal push for Europe.

The existing literature generally tends to focus on the aggregate picture: the dramatic and continuing increase in preliminary referrals to the ECJ, which helped build the European polity we know today. One such string of arguments applies econometric analysis and has launched an ambitious theory of national judicial behaviour (Stone Sweet and Brunell, 1998, 2004). In short, by using econometric tools and aggregated data, Stone Sweet and Brunell claim that the rise in preliminary referrals can be predicted by a rise in transnational activity, and that transnational activity is simultaneously fuelled by the consolidation of legislation. In order to research our puzzle, we test this feedback causality in our paper.

The aim of this paper is threefold: first, to descriptively clarify patterns of variation in the preliminary referral practice in the national courts to the ECJ on the basis of our updated data set; ${ }^{1}$ second, to test the modified neofunctionalist argument that the level of intra-EC trade causes the number of preliminary referrals on the basis of econometric analysis; and, third, to discuss 
alternative determinants that are possibly significant to the referral patterns of national courts. The impact of majoritarian democracy is hypothesized as a causal factor in the hesitation of some member states to participate in the legal push for Europe. The typology of majoritarian democracy includes the Nordic member states as well as the United Kingdom. The impact of majoritarian democracy is assessed by means of panel data analysis.

The paper is structured as follows. First, we briefly describe the historical and contemporary data on the varying referral patterns of national courts. We then present the modified neo-functionalist argument concerning the dynamics behind legal integration. The fourth section tests for the presence and nature of Granger causality between intra-EC trade and the number of preliminary referrals. The following three sections deal with the third aim of this paper, contrasting majoritarian democracy with constitutional democracy, detailing majoritarian democracy by means of case studies focusing on Denmark and the UK, and providing evidence of different sources of referral heterogeneity by means of panel data analysis. The final section provides some concluding remarks.

\section{On variation - the referral patterns of national courts}

The uniformity and expansion of Community law largely depends on the legal push for integration that national courts bring to the ECJ through preliminary referrals, based on Article 234 of the Treaty. Historical and recent data tell us that the national courts have continuously fed the system (Alter, 2000, 2001). As Figure 1 demonstrates, Article 234 referrals continued to increase significantly throughout the examined period from 1961 to 2004 .

Very recent figures confirm this historical trend. By the end of 2004, 5292 preliminary referrals had been made to the European Court. From 1993 onwards, more than 200 referrals were made annually, with a maximum of 264 referrals in 1998.

However, one of the most pronounced characteristics behind the aggregated trend illustrated in Figure 1 is the important heterogeneity of preliminary referral-generation across member states (see Figures 2 and 3). ${ }^{2}$ In Figure 3, the number of referrals has been weighted by population size by dividing a country's total number of referrals in the period by its average population size in the period. The population size figures were offset by two years in order to account for delayed effects. The value for Austria in 2002 is provisional. The value for the UK in 2001 is an estimate. For the UK in 2002, the data were missing and the preceding year was used instead. For Germany, the data on the Federal Republic of Germany are used until 1990 and from 1991 the data include the former GDR. 


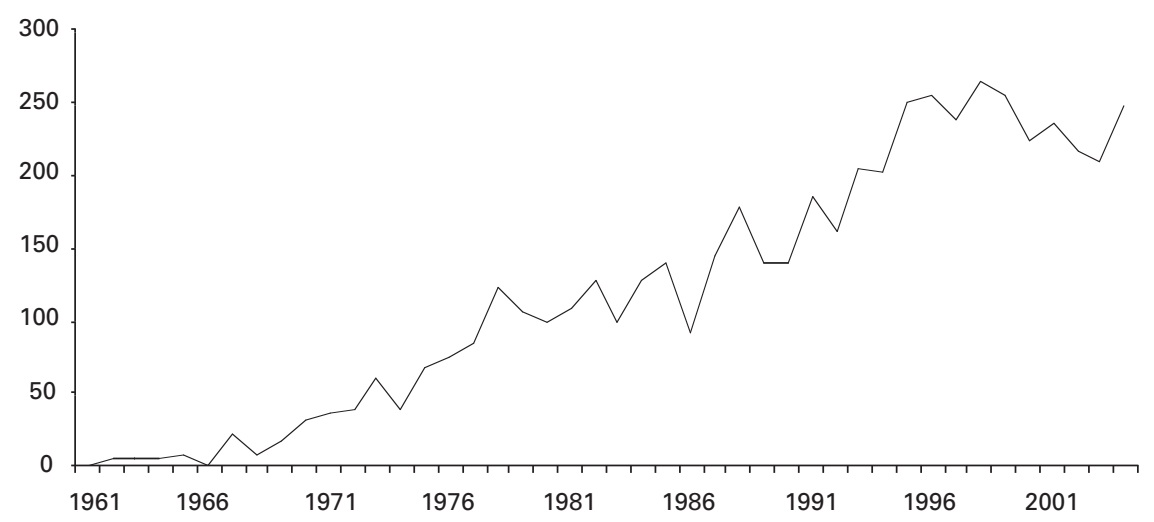

Figure 1 Trend in total number of references.

Source: European Court Reports; own database.

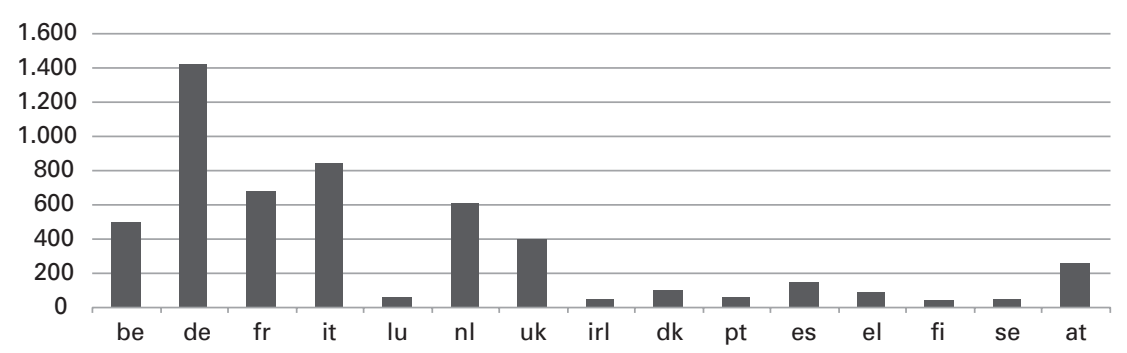

Figure 2 Preliminary references 1961-2004 made by individual member states.

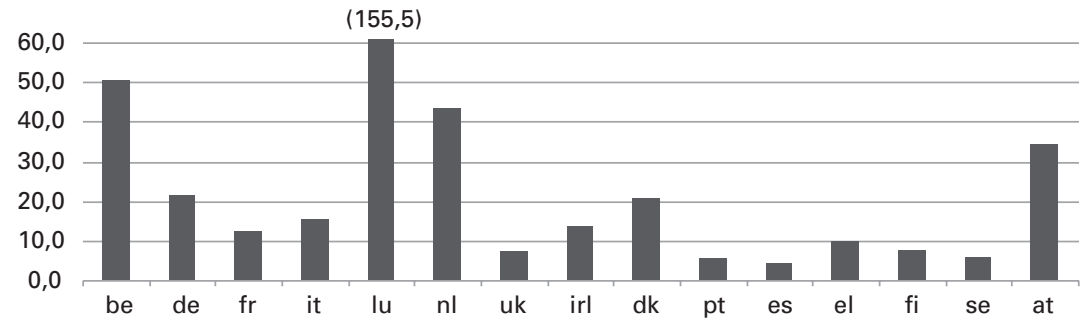

Figure 3 Preliminary references per million inhabitants 1961-2004.

\section{Modified neo-functionalism}

Many observers have been fascinated by the manner in which the national courts and judges who were raised in a very national legal tradition ended 
up indulging in the process of European legal integration (Wind, 2001). As we have seen from examining the entire life-span data of the European Community, the national courts have continued to participate actively in the constitutionalization of Europe. Thus, it is hardly surprising that recent scholarship has been more concerned with detecting general trends and proposing sweeping 'grand theories' regarding the dynamics of European integration than with detecting and explaining why some member state courts have made significantly fewer referrals than others.

One very important theory concerning the dynamics of legal and political integration has been initiated by Stone Sweet and co-authors and labelled 'modified neo-functionalism' (Stone Sweet and Brunell, 1998, 2004; Stone Sweet and Sandholtz, 1998; Fligstein and Stone Sweet, 2002). Although the theory has by no means escaped criticism from various angles (Alter, 2000, 2001; Tsebelis and Garrett, 2001), it has established itself firmly in explaining the processes and causes of European integration. The theory consists of both theoretical abstractions on dynamic institutional integration as well as empirical, econometric testing of the theoretical assertions. The authors thus present a macro theory (Fligstein and Stone Sweet, 2002: 1209), grounded in various sets of data analysis and systematic empirical testing.

One of the important components of the theory is its explicit assumption regarding the causalities of European integration. According to the theory, European integration is driven by a self-reinforcing causal system involving trading, litigation, legislation and lobbying (Fligstein and Stone Sweet, 2002). The integration process is essentially constituted by three causal factors: transnational exchange, dispute resolution and legislation (Stone Sweet and Brunell, 1998). The process is initiated by transnational exchange, which constitutes 'a critical catalyst' for the further steps of integration (Stone Sweet and Brunell, 1998: 65). Among other features, the theory implies the existence of a virtuous circle or feedback system between the three causal factors. The integrative dynamics of this virtuous circle are strengthened by the constitutionalization of the Treaty system, in which the consolidation of the constitutional principles of direct effect and supremacy plays a major role. The theory 'suggests that once the causal connections among exchange, triadic dispute resolutions, and rules are forged, the legal system will operate according to a self-sustaining and expansionary dynamic' (Stone Sweet and Brunell, 1998: 65).

Without doubt, the theory has become a main contribution in addressing the puzzle of this paper: what accounts for the differences between member states in the referral of preliminary questions to the ECJ? As an alternative to existing explanations, Stone Sweet and Brunell argue that variance in crossnational activity creates variance in the production of preliminary referrals (Stone Sweet and Brunell, 1998: 67). 
To test this hypothesis, Stone Sweet and Brunell use the variable transnational activity and apply cointegration analysis. Transnational activity is measured on the basis of intra-EC trade. Stone Sweet and Brunell clarify that they use intra-EC trade as the indicator of transnational activity/transnational exchange, since they find that intra-EC trade is the only reasonable indicator of transnational exchange for which reliable information has been reported annually since the foundation of the European Community (Stone Sweet and Brunell, 1998).

Of the four propositions they test in their analysis, two specifically concern the relationship between transnational activity and preliminary referrals, and thus national courts. The two testable propositions are (Stone Sweet and Brunell, 1998: 66-7):

1. transnational exchange generates social demand for judicial activity, and

2. higher levels of transnational activity will push for an ever-increasing number of supranational judicial or legislative rules.

The authors argue that their econometric analysis supports the view that transnational exchange has been a crucial driving factor behind the construction of the EC legal system, since they find a cointegration relationship between intra-EC trade and Article 177 referrals (Stone Sweet and Brunell, 1998: 69).

On the basis of our constructed database, we test the theoretical argument that a driving dynamic behind national court referrals to the ECJ is the member state's level of intra-EC trade by means of a causality test between intra-EC trade and preliminary referrals by national courts.

\section{Testing causality}

Stone Sweet and Brunell have put forward a causal explanation for the general behaviour of the national courts. They found cointegration, i.e. a long-term relationship, between intra-EC trade and the number of Article 234 (177) referrals for the period 1961-92 and interpret this as evidence supporting their modified neo-functionalist theory (Stone Sweet and Brunell, 1998). They later repeated the analysis for a longer sample, 1961-98, and restated their conclusions (Stone Sweet and Brunell, 2004). As is well known in time series analysis, however, the presence of cointegration implies the presence of Granger causality, but it is silent about the direction of causality; for example, under cointegration, causality might go exclusively from legal to economic integration. 
As pointed out by Granger himself (1969), cointegration is not a necessary condition for Granger causality. Thus, in order to confirm the neo-functionalist prediction, it is not necessary to analyse the presence of cointegration. Pitarakis and Tridimas (2003) explore the direction of causality between the two variables with a test robust to cointegration properties (see Dolado and Lütkepohl, 1996). They find causality from the number of referrals to intra-EC trade but reject the presence of causality from intra-EC trade to the number of referrals, which is contrary to the existence of the virtuous circle predicted by Stone Sweet and Brunell's neo-functionalist arguments. However, Stone Sweet and Brunell do not regard this as compromising their theoretical assumptions when they later refer to the work of Pitarakis and Tridimas (see Stone Sweet and Brunell, 2004).

An important drawback of Pitarakis and Tridimas's approach is the lack of consideration of enlargement effects. The successive enlargements of the European Community automatically increase together with the level of EC trade for each country and the number of referrals, a feature possibly inducing the causality test used by Pitarakis and Tridimas to find causality erroneously (see $\mathrm{Ng}$ and Vogelsang, 2002). In order to assess the validity of Pitarakis and Tridimas's results, we use two causality tests, the one applied by Pitarakis and Tridimas and a causality test robust to enlargement effects (see the Appendix for details). We also conduct our analysis with a longer sample (1961-2004).

When using the Pitarakis and Tridimas approach, we arrive at the same conclusions as the authors; i.e. we do not reject the absence of causality from intra-EC trade to the number of preliminary referrals but reject the absence of causality from the number of referrals to intra-EC trade (see the $p$-values at the bottom of columns 2 and 3 in Table 1).

The detected causal relationship appears rather dubious, however, given that not even a substantial set of preliminary referrals should be able to cause a significant unidirectional increase in intra-EC trade. The validity of the results obtained with the help of the Pitarakis and Tridimas approach is challenged by using a level shifts robust causality test (see $\mathrm{Ng}$ and Vogelsang, 2002). This test first filters the variables for relevant mean shifts and other deterministic terms and then checks causality in relation to the cleaned variables. Two level shifts at 1973 and 1995 are detected with intra-EC trade, and a level shift at 1986 is detected with the number of referrals (see the Appendix for details).

We find no evidence of causality in any direction with the $\mathrm{Ng}$ and Vogelsang test (see the $p$-values at the bottom of columns 4 and 5 in Table 1). As shown in Table 1, the coefficients associated with the first three lags in the referrals variable in the trade equation are all insignificant, in contrast to the 
Table 1 Level shift robust Granger causality test

\begin{tabular}{|c|c|c|c|c|}
\hline \multirow[b]{2}{*}{ Regressors } & \multicolumn{2}{|c|}{ No demeaned variables } & \multicolumn{2}{|c|}{ Demeaned variables } \\
\hline & $\begin{array}{l}R E F_{t} \\
\text { Equation }\end{array}$ & $\begin{array}{l}T_{R A D E_{t}} \\
\text { Equation }\end{array}$ & $\begin{array}{l}R E F_{t} \\
\text { Equation }\end{array}$ & $\begin{array}{l}\text { TRADE }_{t} \\
\text { Equation }\end{array}$ \\
\hline \multirow{2}{*}{$\mathrm{REF}_{t-1}$} & 0.0673 & 0.0644 & 0.0746 & -0.0133 \\
\hline & $(0.1818)$ & $(0.0278)$ & (0.1933) & $(0.0519)$ \\
\hline \multirow[t]{2}{*}{$\mathrm{REF}_{t-2}$} & 0.4212 & 0.0392 & -0.2395 & -0.0170 \\
\hline & $(0.1915)$ & $(0.0293)$ & $(0.1810)$ & $(0.0486)$ \\
\hline \multirow{2}{*}{$\mathrm{REF}_{t-3}$} & 0.2909 & 0.0187 & 0.1991 & 0.0117 \\
\hline & $(0.2000)$ & $(0.0306)$ & $(0.1740)$ & $(0.0467)$ \\
\hline \multirow[t]{2}{*}{$\mathrm{REF}_{t-4}$} & 0.0326 & 0.0042 & -0.1304 & 0.0137 \\
\hline & $(0.1809)$ & $(0.0277)$ & $(0.1719)$ & $(0.0461)$ \\
\hline \multirow[t]{2}{*}{$\operatorname{TRADE}_{t-1}$} & 0.0205 & 0.8587 & 0.2581 & 0.5129 \\
\hline & $(1.189)$ & $(0.1822)$ & $(0.7369)$ & $(0.1977)$ \\
\hline \multirow[t]{2}{*}{$\operatorname{TRADE}_{t-2}$} & -0.1310 & -0.3706 & -1.0344 & 0.1008 \\
\hline & $(1.477)$ & $(0.2262)$ & $(0.8437)$ & $(0.2263)$ \\
\hline \multirow[t]{2}{*}{$\operatorname{TRADE}_{t-3}$} & 0.0941 & 0.4174 & 0.0772 & -0.1513 \\
\hline & (1.479) & $(0.2264)$ & $(0.8453)$ & $(0.2268)$ \\
\hline \multirow[t]{2}{*}{ TRADE $_{t-4}$} & 0.0491 & -0.0485 & -1.150 & 0.1226 \\
\hline & $(1.069)$ & $(0.1637)$ & $(0.7723)$ & $(0.2072)$ \\
\hline \multirow[t]{2}{*}{ Constant } & 0.9400 & 0.0678 & 0.0042 & $(0.0037)$ \\
\hline & $(0.4559)$ & $(0.0698)$ & $(0.0354)$ & $(0.0095)$ \\
\hline \multirow[t]{2}{*}{ Trend } & 0.5028 & 0.0559 & & \\
\hline & $(0.1869)$ & $(0.0280)$ & & \\
\hline \multirow[t]{2}{*}{ Trend $^{2}$} & -0.0056 & -0.0004 & & \\
\hline & $(0.0020)$ & $(0.0003)$ & & \\
\hline Causality Test & 0.9997 & 0.0250 & 0.5274 & 0.9659 \\
\hline
\end{tabular}

results obtained with the previous analysis, which does not correct for level shifts, in which the first lag in the number of referrals is significant. Our results suggest that the causality relationship from legal integration to economic integration found in Pitarakis and Tridimas is the artefact of enlargement effects.

In sum, our causality analysis, which takes into account enlargement effects, rejects the presence of any type of causality between intra-EC trade and preliminary referrals. It is important to emphasize that Granger causality is a dynamic concept requiring one variable to help predict another. The absence of Granger causality therefore does not prevent the possible presence of contemporaneous determinants of the number of referrals. In the next three sections, we discuss the role of potential determinants of contemporaneous variation in the number of referrals and analyse their empirical relevance by means of panel data analysis. 


\section{Alternative determinants of variation}

Having rejected causality between intra-EC trade and preliminary referrals in any direction, we will now discuss a number of alternative potential determinants of the persisting variation in referral rates. We then use panel data analysis to test for the effects on the number of preliminary referrals of a set of independent variables: population size, years of EC membership as an indicator of learning, intra-EC trade, enlargements introducing level shifts, and the potential effect of the form of democracy. Whereas the likely impact of the first set of independent variables has been discussed in the existing literature, we focus on the last set as the main hypothesis of this paper. Our hypothesis is that member states with the institutional legacy of majoritarian democracy are more reluctant to participate in the construction and maintenance of the judicial constitutionalization of Europe. In this section, we will present the key characteristics of majoritarian democracy versus constitutional democracy that are argued to matter in the referral practice of EU member states. We then further detail the characteristics of majoritarian democracy by means of two case studies: Denmark and the UK. We will examine some of the determining institutional features explaining why judges who might gain from challenging the national legal hierarchy - from a narrow point of view - tend not to do so.

Existing studies have provided very different explanations regarding the degree to which individual member states have participated in the legal constitutionalization of Europe. Among the explanatory factors pointed out by existing studies are the extent to which a policy area is captured by interest group politics (Alter, 2000; Alter and Vargas, 2000), the litigiousness of individual societies (Alter, 2000; Conant, 2001), national legal education (Alter, 2000), judicial learning (Golub, 1996a), the calculative or strategic behaviour of judges and inter-court competition (Golub, 1996b; Alter, 2001), and domestic politics (Golub, 1996b).

These explanations are highly plausible for explaining the referral practice of individual countries or within different sectors of politics. The hypothesis of majoritarian democracy, however, focuses on a different set of structuring institutions. The hypothesis holds that the institutional features of law and politics and the traditional means of organizing their mutual relationship might influence the willingness of national courts to refer matters to the ECJ. The assumption is that countries with an institutional and democratic tradition of majoritarian democracy are more reluctant, perhaps even sceptical, about referring preliminary questions to a supranational authority than are countries that are rooted in some variant of constitutional democracy, where the judicial review of legislation by courts is part of what defines good 
'democratic governance' (Dworkin, 1996). Below, we draw out the main traits characterizing majoritarian versus constitutional democracy. Since we are specifically concerned in this paper with explaining why some member states have made less use of the preliminary ruling procedure, we also present two case studies from the majoritarian camp in order to provide more qualified information about why national courts and judges may choose not to play the game of engaging in supranational judicial review.

Majoritarian democracy is rooted in the notion of parliamentary supremacy or sovereignty. The parliament (but not necessarily the government) is perceived as a majoritarian institution forming the centre of government (Dworkin, 1996; Ginsburg, 2003). The role of the courts is limited in majoritarian systems. For this reason, it has become commonplace to view constitutional and majoritarian democracy as almost incommensurable: 'The ideal of limited government, or constitutionalism, is in conflict with the idea of parliamentary sovereignty' (Ginsburg, 2003: 2). Parliamentary governance systems are founded upon the notion that parliamentary majorities represent the 'will of the people' and that such majorities should not be subject to judicial review (Dworkin, 1996: 19-20). Courts and judges are not accountable to the people, and the right of the courts to strike down legislation otherwise enjoying majority support places unacceptable limits on the popular will and on democracy as such (Freeman, 1990: 332ff; Dworkin, 1996: 21ff). In this reading, courts are regarded as a 'counter-majoritarian' force on the grounds that they place the protection of rights and civil liberties by the courts above 'the will of the people'.

It is important to emphasize that most majoritarian democracies have constitutions that speak of the balance of power principle and even some kind of court review. In actual practice, however, there has been little tradition in these democracies of the courts challenging or actively reviewing legislation in accordance with the constitution (Scheinin, 2001). Denmark, Sweden, Finland and the UK all have roots in this tradition. The UK has no written constitution, and the idea of parliamentary sovereignty has always been extremely strong (Chalmers, 2001; Dworkin, 1996). Accordingly, the courts have had almost no powers of legislative review and have generally regarded themselves as 'la bouche de la loi'; loyal primarily to the executive and the democratically elected majority (Chalmers, 2001; Volcansek, 1992). In Finland, the judicial review of legislation was directly forbidden up until a very recent amendment to the constitution in 2000 (Nergelius, 2001: 85). In Sweden and Denmark, the review of legislation is formally allowed but almost never practised. The Danish courts have set aside legislation only once in the past 150 years (Nergelius, 2001). Moreover, the Nordic countries share a conception of democracy in which the parliament is conceived as a superior 
institution vis-à-vis the other branches of government. This perception of democracy is echoed in the public debate, which 'tend[ed] to conflate legitimacy and majoritarian parliamentarism' (Føllesdal, 2002: 183). Moreover, the majoritarian paradigm in the Nordic countries has cultivated 'a corps of judges who are unusually loyal to the legislator, never questioning his wisdom and not perceiving its task as protecting the rights of the individual against the state' (Nergelius, 2001: 88).

Constitutional democracy is mainly an American invention, which only gradually came to influence a number of European countries after World War II. Using Ronald Dworkin's classical terminology (Dworkin, 1996: 15-26), so-called 'constitutional democracies' generally embrace judicial review and view it as a constitutive aspect of what it means to be a true democracy. Supranational judicial review at the European level is therefore perceived as a natural extension of national practice; not as a threat. The theoretical as well as the descriptive literature has recently drawn out some very general trends characterizing constitutional democracies in Europe and elsewhere (Dworkin, 1996; Ginsburg, 2003; Kenny et al., 1999; Scheinin, 2001; Shapiro, 1999; Shapiro and Stone, 1994; Sheive, 1995; Stone Sweet, 1999, 2002). These studies often emphasize that judicial review became a reality in Europe after World War II when the defeated powers, Germany and Italy, adopted the institution. Even France had - by the Fifth Republic - introduced a form of constitutional review through the Constitutional Council (Shapiro, 1999: 199; Sheive, 1995: 5-8; Stone Sweet, 1992, 1999). ${ }^{3}$ In reality, however, there has been great variation in the manner in which judicial review was institutionalized in different European countries (Kenny et al., 1999). Research suggests that historical and institutional factors such as court structure, monism/dualism and experience with dictatorship and/or communist rule influence the emphasis countries place on judicial review and the need for limiting parliamentary power (Magalhães, 1999; Sheive, 1995; see also Ginsburg, 2003; Stone Sweet, 2002). For example, the Benelux countries have not practised judicial review in a manner parallel to that of Germany, Austria, Italy and Spain. In the Benelux countries, monism and the primacy of international law over national law appear to carry much more explanatory power - including when it comes to explaining the willingness of these countries to participate in the dialogue with the ECJ. The Benelux countries all have rather strong monist traditions, where 'treaty law is a law of superior nature, stemming from higher origins than domestic organs; consequently, international laws prevail over national laws', as the Luxembourg Cour supérieure de justice noted in 1954 (Bribosia, 1998: 35). ${ }^{4}$ In monist legal orders, it is the international 'constitution' that places limitations on the national ruling majority (Mattli and Slaughter, 1998: 275). 
Despite these institutional and historical differences, the introduction of the EU preliminary ruling system has had a strong impact on the 'European model' of judicial review. In the European model of judicial review, the power to try statutes is relegated to special constitutional courts, whereas in the US model of judicial review all courts can try the constitutionality of any law (Stone Sweet, 1999: 9). By shifting judicial review from the high courts to midlevel and lower courts, Europe has increasingly come to resemble the USA in the sense that all of the judicial bodies (in theory at least) are involved in controlling the legislative output from the EU (Shapiro and Stone, 1994). We will now briefly explore key institutional features of law and politics in two of the member states belonging to the majoritarian democracy type. We argue that these institutional factors structure Court behaviour and explain in part why national courts within this type are more reluctant to refer questions to the ECJ.

\section{When courts don't go to Europe: Denmark and the UK}

Majoritarian democracies have an institutionalized reluctance about bringing political decisions to the courts for clarification. This reluctance is likely to be intensified when such clarification is externalized, taking place outside of the national system. In the following, we first examine Denmark, where our qualitative data indicate that preliminary referrals have generally been avoided through close cooperation between the national courts and the Danish executive. We then examine the UK case, in which the national courts have long deliberately disregarded the possibility of externalizing legal clarification but recently appear to have undergone a process of change in which preliminary referrals occur more frequently. Even where 'judicial learning' appears to have developed, however, it proceeds in a rather 'sectorized' manner, i.e. within specific regulatory fields.

\section{The Danish case}

The Nordic countries all belong in the category of majoritarian democracies and the category of 'reluctant Europeans', at least as regards making preliminary referrals. We are dealing with a group of countries regarding themselves to be not only unique egalitarian welfare states but equally 'highly homogenous, religiously, culturally and ethically' (Føllesdal, 2002: 182). These features have contributed to the development of a consensus culture in which as many disputes as possible are solved outside the courtroom and where 'going to court' - perhaps in particular when it comes to being brought before 
an international court - is avoided whenever possible (interview, Danish Ministry of Foreign Affairs, September 2005 and survey).

As a European Community member since 1973, Denmark should be more or less 'socialized' in relation to the European legal system; however, this appears to be far from the case. A study conducted by Pagh (2004) of the preliminary referral procedure in Denmark has pointed to the extraordinarily close cooperation between the executive branch (the Ministry of Justice and Foreign Affairs) and the Danish courts. Historically, there has always been a close relationship between the Ministry of Justice and the national courts. Until 1999, Danish judges were exclusively recruited from the Ministry of Justice, and loyalty to this executive body remains almost unchallenged (Christensen, 2003: 75-90; interviews with Danish judges and civil servants, March 2006). This explains, at least in part, the influential role of the Judicial Committee as regards preliminary referrals. The Judicial Committee was established in 1973 and is a government committee consisting of high-ranking civil servants from the relevant ministries. The chair is held by the Ministry of Justice. In his study, Pagh demonstrates not only how the Ministry of Justice, together with the Ministry of Foreign Affairs through the Judicial Committee, participates in the selection and drafting of questions on Article 234 to the ECJ when a national court considers whether to refer or not, but also that the Committee advises the government in the implementation of EU law (Pagh, 2004). Moreover, the Judicial Committee is an important player when it comes to infringement cases against the Danish state and acts as a drafter of those written interventions that all governments can submit for cases pending before the ECJ. The Judicial Committee thus plays several roles and has highly conflicting interests.

Because there is no tradition of the judicial review of legislation in Denmark, the preliminary referral procedure has been regarded with considerable suspicion, both at the national administrative level and within the courts themselves (Pagh, 2004; own research). Danish courts have thus repeatedly invoked the acte claire doctrine and generally - in nice accordance with its strict dualist tradition - made efforts to interpret the compatibility between Danish and EU law themselves (Pagh, 2004).

The Danish constitution formally refers to a division of powers between the different branches of government, noting that 'Judicial authority shall be vested in the courts of justice'. Nevertheless, the Judicial Committee has been involved in the drafting of preliminary referrals by the courts since 1978 (Pagh, 2004: 305). Our research shows that, because of its many overlapping and occasionally contradictory tasks, the Judicial Committee will have very few incentives to recommend to the national court to make a preliminary referral. A comprehensive survey conducted amongst all Danish judges in the winter of 2006 on this issue confirmed that one of the main reasons for 
the low number of preliminary referrals was discouragement from the legal adviser to the Danish government based on a so-called 'responsa' by the Committee. ${ }^{5}$ Asked specifically about the main reason for not making any (or very few) preliminary referrals, an overwhelming $69.8 \%$ referred to discouragement from the state adviser. Since it is not required in Denmark to report when a preliminary referral has been requested from one or both of the parties to a case (but rejected by the courts), we have only a vague sense of the relationship between the number of cases actually referred and the number of requests for preliminary referrals made in court by parties to a case. ${ }^{6}$ According to Pagh, however, the involvement of the Judicial Committee is the most convincing single explanatory factor in the low number of referrals from Danish courts since Denmark became a member of the European Community. Pagh's study shows that between 1986 and 2003 the Judicial Committee recommended not referring a case to the ECJ in 20 out of 26 cases, even though all 26 cases dealt with the interpretation of EU law and at least one of the parties had requested an interpretation by the ECJ (Pagh, 2004: 307). Generally speaking, the Judicial Committee has recommended Danish courts to make preliminary referrals only in those cases where direct action is already being taken against Denmark by the Commission. ${ }^{7}$

Interestingly, civil servants dealing with preliminary referral issues in the Foreign Ministry go so far as to note openly that there are courts that we cannot control' (interview, Danish Ministry of Foreign Affairs, September 2005), implying that there was indeed an instance or two in which a lower Danish court referred a case to the ECJ against the will of the Judicial Committee. Referring cases without the Committee's consent is unusual. In our survey, $41.1 \%$ of the judges in the lower courts stated that it is up to the High Court alone to decide whether or not a case ought to be referred to the ECJ. The legal hierarchy that the preliminary ruling procedure in many ways was established to challenge has thus gone untouched in the Danish case.

It is important to note, however, that a common understanding exists amongst civil servants and judges that it is important for the two branches to work closely together to avoid ex post demands for supranational legal clarifications. It can also be argued that the involvement of the Judicial Committee in the early years of Danish EC membership may be excused with reference to unfamiliarity with judicial review and EC law in general. In the early years, when the national courts were in a learning process, the need for specialized advice may have been legitimate. However, such initial problems can hardly explain why the Judicial Committee continues to influence the degree to which cases are referred to the ECJ. 


\section{The UK case}

In the UK, the doctrine of parliamentary sovereignty has long ruled the relationship between the judiciary and parliament. This doctrine establishes that British courts do not possess the power to declare a parliamentary act unconstitutional (Dworkin, 1996: 352ff). Ultimate power is placed in the hands of the people, as represented by Parliament. The traditional hegemonic position of Parliament is deeply embedded in the relationship between the law and politics; politics comes first and courts are considered to be an antimajoritarian force even by lawyers. Even British 'lawyers say that Parliament is an absolute sovereign because that seems (for most of them intuitively and unreflectively) the best interpretation of British legal history, practice, and tradition' (Dworkin, 1996: 360). In addition to structuring domestic politics, we argue that the doctrine of parliamentary sovereignty is a major explanation of why British courts have been reluctant to refer preliminary cases to the ECJ. When the historically institutionalized understanding of democracy determines that the final word always rests with Parliament and not with the courts, this institutional legacy is likely to prevail for decades and restrain judicial behaviour, although in principle reversed by the norms and rules of Community law.

As traditionally governed by the sovereign Parliament, the British courts had no power of legislative review (Chalmers, 2001: 173; Craig, 1998; Dworkin, 1996). In principle, the British courts were therefore strongly empowered by the UK's entry into the European Community in 1973. The 1972 European Communities Act stated that, in the event of conflict between British law and EC law, the latter should prevail. The act also stated that possible disputes regarding the interpretation or effect of Community law ought to be treated as a matter of law by British courts, and the highest British court of appeal - the House of Lords - was obliged to refer disputes to the ECJ; lower courts could also do so (Norton, 1994: 326).

In principle, the EC law thereby challenged the division of labour between politics and law in the UK, and thus the supreme position of Parliament. However, the British courts did not explicitly accept EU law supremacy before the Factortame case in 1990. As concerns preliminary rulings, these were simply not made during the first decades of membership (Craig, 1998: 200-5). In his study, Golub found that instead of referring EC-relevant environmental cases to the ECJ, the British courts consistently invoked the acte claire doctrine and interpreted the directives themselves (Golub, 1996b: 369; Craig, 1998: 205-6). As in the Danish case, acte claire was used intensively by British courts and strongly encouraged by authoritative figures such as Lord Denning. ${ }^{8}$ In Bulmer, Denning instructed British judges to clarify matters 
themselves rather than sending preliminary referrals to the ECJ (Bulmer v. Bollinger, 1974, 3 Weekly Law Reports 202; Craig, 1998: 205; Golub, 1996b: 372). This general invocation of acte claire restricted the behaviour of the British courts vis-à-vis the ECJ for approximately a decade and in part explains the low British referral rate until the mid-1980s. Later guidelines came to narrow the discretion of the British judiciary (Golub, 1996b: 372). In the ApS Samex decision (1983), it was suddenly found that the use of acte claire should be limited, since 'the ECJ was in a far better position than a national court to determine issues of Community law' (Customs and Excise Commissioners v. ApS Samex, 1 All England Law Reports 1042 (1983); Bingham cited in Craig 1998: 206). The decision has subsequently been interpreted as yet another authoritative guideline for British judges when considering whether or not to refer to the ECJ. The recognition of the need to refer certain matters supranationally may explain the limited increase in referrals from the UK in the late 1980s. Furthermore, the Factortame judgment in 1990 made irrevocably clear that British courts could suspend an Act of Parliament that breached EC law (Chalmers, 2001; Craig, 1998: 207-9; $R$ v. Secretary of State for Transport exparte Factortame, (No 1) [1990] 2 AC 85).

Although British referral practice has undergone change, we argue that majoritarian democracy continues to serve as a structuring factor. First, the authoritative guidelines to invoke acte claire offered an efficient means to shield the national system and thus ultimately majoritarian sovereignty. It thus represented an instrument for maintaining the historically institutionalized division of labour between the courts and politics. Second, the identified judicial learning appears rather 'sectorized'. According to the statistical work carried out by Chalmers, EC law was invoked in the British courts within a very narrow focus, mainly concerning taxation, sex discrimination, free movement of goods, free movement of persons and intellectual property. Furthermore, the invoking was centred around single items of EC legislation or Treaty provisions (Chalmers, 2001: 179). The narrow and sectorized learning pattern is confirmed by our data analysis, in which the preliminary referrals of each member state have been classified according to regulatory field. Of 104 possible regulatory fields, $44 \%$ of the British referrals fell narrowly within just six bands; agriculture $(10 \%)$, social provisions, including sex discrimination $(10 \%)$, taxation $(7 \%)$, free movement of goods $(6 \%)$, Value Added Tax (6\%) and social security for migrant workers (5\%).

In sum, majoritarian democracy in Denmark and the UK produces similar 'filters' when national courts approach the ECJ, which shield the national system to different degrees. First, the institutionalized division of labour between law and politics rests on the supreme position of politics. Executive institutions, such as the Danish Judicial Committee, may indeed control when 
and how national courts address the supranational legal system. Second, the doctrine of acte claire offers an effective means of hindering the formulation of questions to the ECJ. Third, learning may take place, but still tends to unfold as rather sectorized learning. Such key institutions are the main factors explaining why national courts embedded and socialized within the institutional legacy of majoritarian democracy tend to remain reluctant Europeans.

\section{Testing determinants on variation - panel data analysis}

In order to determine the relative impact of majoritarian democracy on the number of referrals, we estimate a panel data model for the number of referrals (per million inhabitants in logs) of member state $i$ at year $t .{ }^{9}$ We chose the following member state characteristics: intra-EC trade per million inhabitants in logs, years of EC membership, a majoritarian democracy dummy indicator, national population (in logs), dummy variables for the year of entry into the EC, and level shift variables for the series of EC enlargements.

Longitudinal data take advantage of both time and national variation, thus allowing the inclusion as potential determinants of the number of referrals of variables that change only across countries, such as majoritarian democracy, variables that change only across years, such as EC enlargements, and variables that change over time and country, such as intra-EC trade. An important feature of the panel data models is that it becomes possible to account for unobservable country heterogeneity, for example qualitative differences in judicial systems or in the implementation process.

We estimate the panel data model as a random-effects model with generalized least squares (GLS). ${ }^{10}$ The estimation results are presented in Table 2. As Table 2 shows, the estimates produce several interesting results.

First, ceteris paribus, population size is not significant.

Second, years of membership has practically no effect on majoritarian democracies, and a negative effect on countries without majoritarian democracy. For these countries, an extra year of membership reduces referrals per million inhabitants by $5.6 \%$. This result implies that the difference in terms of referrals between the two types of democratic organization slowly declines with years of membership, such that, after three years as EC members, countries with majoritarian democracy refer $55.0 \%$ less than non-majoritarian democracies, and after 12 years in the EC the gap is halved and majoritarian democracies refer $26.8 \%$ less than countries without this type of democracy. The hypothesis that the institutional legacy of majoritarian democracy tends to make national courts considerably more reluctant to bring cases to a supranational system of judicial review is thus supported. 
Table 2 GLS estimation of random-effects panel data model

\begin{tabular}{|c|c|c|}
\hline Explanatory variables & Model 1 & Model 2 \\
\hline Founding member & $\begin{array}{c}1.064^{*} \\
(0.577)\end{array}$ & $\begin{array}{c}1.036^{*} \\
(0.552)\end{array}$ \\
\hline Country enters the EC in 1973 & $\begin{array}{c}-0.281 \\
(0.405)\end{array}$ & $\begin{array}{c}-0.319 \\
(0.396)\end{array}$ \\
\hline Country enters the EC between 1981 and 1986 & $\begin{array}{l}-0.917^{* *} \\
(0.417)\end{array}$ & $\begin{array}{l}-0.966^{* *} \\
(0.408)\end{array}$ \\
\hline EC enlargement 1973 & $\begin{array}{l}0.891 * * * \\
(0.211)\end{array}$ & $\begin{array}{l}0.933^{* * *} \\
(0.261)\end{array}$ \\
\hline EC enlargement 1981 & $\begin{array}{l}0.528 * * * \\
(0.182)\end{array}$ & $\begin{array}{l}0.531 * * * \\
(0.188)\end{array}$ \\
\hline EC enlargement 1986 & $\begin{array}{c}0.126 \\
(0.171)\end{array}$ & $\begin{array}{c}0.114 \\
(0.172)\end{array}$ \\
\hline EC enlargement 1995 & $\begin{array}{c}0.299^{*} \\
(0.180)\end{array}$ & $\begin{array}{c}0.292 \\
(0.180)\end{array}$ \\
\hline Majoritarian democracy & $\begin{array}{l}-0.960 * * * \\
(0.305)\end{array}$ & $\begin{array}{l}-0.991 * * * \\
(0.355)\end{array}$ \\
\hline Majoritarian democracy * years since membership & $\begin{array}{l}0.054^{* * * *} \\
(0.018)\end{array}$ & $\begin{array}{l}0.055^{* * *} \\
(0.020)\end{array}$ \\
\hline Intra-EC trade per mill. inhab. & $\begin{array}{c}-0.099 \\
(0.376)\end{array}$ & $\begin{array}{c}-0.282 \\
(0.561)\end{array}$ \\
\hline Intra-EC trade per mill. inhab.* years since membership & & $\begin{array}{c}0.003 \\
(0.005)\end{array}$ \\
\hline Years since membership & $\begin{array}{c}-0.058^{*} \\
(0.033)\end{array}$ & $\begin{array}{c}-0.053^{*} \\
(0.032)\end{array}$ \\
\hline Years since membership ${ }^{2}$ & $\begin{array}{c}0.001 \\
(0.001)\end{array}$ & $\begin{array}{c}0.001 \\
(0.001)\end{array}$ \\
\hline Population & $\begin{array}{c}-0.664 \\
(0.455)\end{array}$ & $\begin{array}{c}-0.818 \\
(0.576)\end{array}$ \\
\hline $\mathrm{R}^{2}$ within & 0.400 & 0.401 \\
\hline $\mathrm{R}^{2}$ between & 0.836 & 0.836 \\
\hline$p$-value of Wald test for joint significance & $0.000 * * *$ & $0.000 * *$ \\
\hline Hausman Test & 0.90 & 0.91 \\
\hline
\end{tabular}

Third, our analysis confirms that intra-EC trade has no significant effect on the number of preliminary referrals. Note that Granger causality can also be tested in a panel model, where it is possible to allow that causality between number of referrals and intra-EC trade might vary across different countries (see, for example, Holtz-Eakin et al., 1985). However, as is well known in time series analysis, the presence of causality in some direction between referrals and trade in some countries implies the presence of causality at the level of aggregated referrals and aggregated trade (see Lütkepohl, 1991). 
Two specifications made in Models 1 and 2 for the intra-EC trade effect are attempted. In contrast to Model 1, Model 2 allows interaction between intra-EC trade and years since membership in order to capture the possible changing effect of intra-EC trade for those countries with more experience as EC members (in the spirit of Stone Sweet and Brunell, 1998). As seen in Table 2, none of the regressors, including intra-EC trade, is significant.

Fourth, EC enlargements, occurring in 1973, 1981 and 1995, have a positive impact on referral generation.

Finally, the dummy for countries entering the EC between 1981 and 1986, e.g. Spain, Portugal or Greece, has a negative effect, which may partly reflect the less developed judicial systems of these countries. Explanatory factors for the more reluctant referral patterns in the southern member states call for more in-depth analysis combining quantitative findings with qualitative method explanations.

\section{Concluding remarks}

European integration continues to have a strong judicial component, in which the European Court of Justice plays a crucial role in clarifying, substantiating and setting the direction Europe is to take. In this process of clarifying and substantiating the content of Europe, national courts constitute pivotal players. However, national courts are not participating evenly in this legal push for Europe.

In this paper, we have tested the causality assumption of the modified neo-functional approach, which argues that the driving dynamic behind court referrals to the ECJ is the level of intra-EC trade. Our findings reject causality between intra-EC trade and preliminary referrals in any direction. The level of economic integration does not explain or predict legal integration; or vice versa for that matter.

Our panel data analysis supports the hypothesis that member states with majoritarian democracy are less inclined than others to participate in the legal construction of the EU. The strong negative effect of majoritarian democracy on the preliminary referral rates of individual member states suggests that the institutional legacy of the type of democracy that continues to emphasize the supremacy of parliament and thereby to restrain judicial behaviour may prevail for decades. Our findings thus propose that majoritarian government and the internal balance of power between different governmental branches in the member states may affect the extent to which national courts willingly participate in the (judicial) construction of Europe.

The panel data analysis cannot do it alone, of course; and the analytical results derived invite further comparative research. Such future research 
should aim to further unpack the institutions of majoritarian democracy and how these may function as built-in shields that structure and delimit the approach to Europe. Such shields and practices ought to be examined over time, because they are clearly not static or unbending, but may prove to be strong. Our findings suggest that the normative power of majoritarian democracy in European societies may go beyond scepticism towards legal integration and extend to a general scepticism towards the European polity, because the supranational construct essentially compromises the founding idea of parliamentary sovereignty.

The implications of the uneven legal push for Europe are significant. When some member states remain at arms' length from the legal integration process, they do not bring the questions determining significant parts of the direction and scope of the European polity in a piecemeal manner. Nor are their systems, policies and citizens confronted or integrated to quite the same extent as those in other parts of the enlarged and expanding EU.

\section{Appendix: Granger causality analysis robust to cointegration and level shifts}

The Granger causality analysis is typically carried out by means of a vector autoregressive model $(\operatorname{VAR}(k))$, which is a model explaining the joint dynamics of a set of variables, in this case intra-EC trade (TRADE) and number of referrals $(R E F)$, by means of a $\operatorname{VAR}(k)$ model:

$$
\begin{aligned}
& R E F_{t}=\mu_{1}+v_{11} t+v_{12} t^{2}+a_{1} R E F_{t-1}+\ldots+a_{k} R E F_{t-k}+b_{1} \\
& \operatorname{TRADE} E_{t-1}+\ldots+b_{k} \operatorname{TRADE}_{t-1}+e_{1 t} \\
& \mathrm{TRADE}_{t}=\mu_{2}+v_{21} t+v_{22} t^{2}+c_{1} R E F_{t-1}+\ldots+c_{k} \mathrm{REF}_{t-k}+d_{1} \\
& \operatorname{TRADE}_{t-1}+\ldots+d_{k} \operatorname{TRADE}_{t-1}+e_{2 t}
\end{aligned}
$$

where $R E F_{t}$ is the total number of referrals at year $t, T R A D E_{t}$ is the intra-EC trade at year $t, R E F_{t-1}$ is the total number of referrals at year $t-1$, $T R A D E_{t-1}$ is the intra-EC trade at year $t-1, \mu_{1}$ is an intercept, $t$ is a linear trend, $t^{2}$ is a quadratic trend, and $e_{1 t}$ and $e_{2 t}$ are error terms serially uncorrelated.

REF Granger is said to cause TRADE when the past of REF helps predict the future of TRADE, which in terms of this model implies that at least one of the $c_{1}, \ldots c_{k}$ coefficients is different from 0 . The hypothesis tested is the absence of Granger causality. Then REF does not cause TRADE when $c_{1}=$ $\ldots=c_{k}=0$, and TRADE does not cause REF when $b_{1}=\ldots=b_{k}=0$. The Granger causality approach in Dolado and Lütkepohl (1996) does not require knowing about the cointegration properties of the data. The only aspects of the model that must be determined are the lag length $k$, which in the case of 
annual data is rarely greater than 4 , and whether the deterministic component should include a constant only, a constant and a linear trend, or a constant, a linear trend and a quadratic trend.

Once all of these features are determined, a Wald test statistic for joint significance of the first $k$ lags in a $\operatorname{VAR}(k+1)$ is a test of Granger causality. For example, in the case of $k=3$, a VAR(4) model is used, and the absence of causality from TRADE to REF is tested by testing that condition $b_{1}=b_{2}=$ $b_{3}=0$ holds, and the absence of causality from REF to TRADE is tested through the condition $c_{1}=c_{2}=c_{3}=0$.

If there are level shifts, i.e. the intercept changes over the sample period, the preceding test tends to find causality even when there is not. Following the recommendation of $\mathrm{Ng}$ and Vogelsang, detecting the location of mean shifts is necessary, removing the deterministic component, including the level shifts, from the data, and subsequently performing the usual causality test with the de-trended data. To do this, we allow for a maximum of three mean shifts and restrict the dates to the immediate years of the EC-9, EC-12 and EC-15 enlargements, and use the Bai and Perron (1998) method to detect the dates of the shifts. We find one mean shift in the variable REF for the year 1986 and two mean shifts in TRADE coinciding with the EC-9 and EC-15 enlargement years 1973 and 1995. The only difference with respect to the Pitarakis and Tridimas analysis is the inclusion of a quadratic trend in the VAR model. The results also apply in the case of a linear trend.

Appendix Table 1 Deterministic component of $\mathrm{REF}_{\mathrm{t}}$ and $\mathrm{TRADE}_{\mathrm{t}}$ variables

\begin{tabular}{|c|c|c|}
\hline & $R E F_{t}$ & $T R A D E_{t}$ \\
\hline Constant & $\begin{array}{c}1.1365 \\
(0.1314)\end{array}$ & $\begin{array}{c}-0.0748 \\
(0.0395)\end{array}$ \\
\hline Trend & $\begin{array}{c}0.2343 \\
(0.0127)\end{array}$ & $\begin{array}{c}0.1642 \\
(0.0063)\end{array}$ \\
\hline Trend $^{2}$ & $\begin{array}{c}-0.0029 \\
(0.0003)\end{array}$ & $\begin{array}{c}-0.0014 \\
(0.0001)\end{array}$ \\
\hline Dummy 1973 & & $\begin{array}{c}0.5093 \\
(0.0523)\end{array}$ \\
\hline Dummy 1986 & $\begin{array}{c}-0.4411 \\
(0.1466)\end{array}$ & \\
\hline Dummy 1995 & & $\begin{array}{c}0.1154 \\
(0.0541)\end{array}$ \\
\hline Impulse 1961 & $\begin{array}{c}-1.3679 \\
(0.2640)\end{array}$ & \\
\hline Impulse 1966 & $\begin{array}{c}-2.4383 \\
(0.2466)\end{array}$ & \\
\hline
\end{tabular}


The dataset, do-file, and additional tables for the empirical analysis in this article can be found at http://eup.sagepub.com/supplemental/

\section{Notes}

We would like to thank research assistant Mogens Hobolth for his excellent help on this paper. Furthermore, we are very grateful to Joseph Weiler, Gráinne de Burca, Andreas Føllesdal, Martin Scheinin, Claus Gulmann and Helle Porsdam for their comments on a much earlier draft of this paper. Our thanks also go to the editor and the reviewers of European Union Politics for their very constructive criticisms.

1 The research for this paper has combined quantitative analysis with qualitative case-study methods. For the quantitative part, we constructed a database in which all preliminary referrals to the European Court of Justice in the period 1961-2004 were coded. The preliminary referrals were crossexamined and coded in relation to the referring member state, membership period, population size and level of intra-EC trade in relation to GDP. The judgements have also been coded according to the regulatory field and the court level of the referring national court. The qualitative research consists of a series of interviews with key respondents among lawyers and civil servants. In addition, a survey of 380 Danish judges was conducted.

2 Case C-265/00 is recorded by the ECJ as submitted by Benelux and has therefore been excluded from this figure. Hungary was also excluded; it was the only country among the 10 new member states to submit referrals in 2004 (two in total - ECJ, 2005). The official EU acronyms are used: be = Belgium, de $=$ Germany, $\mathrm{fr}=$ France, it $=$ Italy, lu = Luxembourg, $\mathrm{nl}=$ Nether lands, $\mathrm{uk}=$ United Kingdom, irl = Ireland, $\mathrm{dk}=$ Denmark, $\mathrm{pt}=$ Portugal, es $=$ Spain, el $=$ Greece, $\mathrm{fi}=$ Finland, $\mathrm{se}=$ Sweden, at $=$ Austria.

3 As Martin Shapiro comments: 'All things considered, I would opt for claiming that the French indeed have achieved a flourishing judicial constitutional review, peculiarly limited by its abstract only character but still roughly comparable to constitutional judicial review elsewhere' (Shapiro, 1999: 199). This is supported by the analysis presented by Sarah Wright Sheive, who directly compares the German Constitutional Court and the French Constitutional Council in an article written in 1995. The Council approves all significant legislation, and the Council's abstract review power is a very effective remedy for the parliamentary minority, which has often exploited this possibility to force the government to amend new legislation. The same pattern is found in Germany, where the 'parliamentary majority is even more risk averse in constitutional matters', attempting to avoid new legislation being forwarded to the Court (Sheive, 1995: 9). Moreover, the power of the constitutional bodies in both France and Germany is underlined by the fact that 'no legislative text has been invalidated after having been amended in response to a constitutional court decision' (Sheive, 1995: 9). As Sheive points out, the French Constitutional Council is in fact often regarded as the most anti-majoritarian of all European constitutional courts, because it practises only a priori abstract review. This allows the constitutional court to forcefully 
influence policy initiatives by parliaments and thus act as a second legislative branch (Sheive, 1995: 10).

4 Monism as an explanatory factor is most apparent in the Netherlands and Luxembourg, where international law (and thus also EU law) is regarded as the higher law of the land (see Claes and de Witte, 1998). However, as Bribosia (1998) has shown in his study of Belgium and the EU legal order, Belgium also quickly accepted the EU legal order as superior (in 1971).

5 The 17-page questionnaire was sent to all (380) of the judges in Denmark; $62 \%$ of them responded.

6 It has become obligatory in Sweden for the national courts to explain why a case has not been referred to the European Court of Justice when one of the parties to a case has requested doing so. Law No. 502/2006 was adopted on 24 May 2006. The reason was a letter of formal notice sent by the European Commission in October 2004 to the Swedish government. It argued that far too few preliminary requests were made by Swedish courts - and in particular the Highest Court (Högsta Domstolen) - to the ECJ. Until this new statute was adopted, Swedish courts - as is the case in Denmark today - could refuse to make preliminary requests to the ECJ without accounting for the reasons for not doing so.

7 In particular, the infamous 'can case', Case C-246/99, in which Denmark was charged by the Commission for hindering the implementation of Directive 94/62 dealing with the marketing of cans instead of ordinary bottles in the Danish market.

8 According to Lord Denning, a national court possessed discretion as whether to refer a case or not and the following elements should be borne in mind before such a radical step was taken: (a) the length of time it takes to process a case in the ECJ; (b) the ECJ should not be overloaded with cases; (c) cases should not be referred unless the point of Community law was important and difficult; (d) the national court should bear in mind the costs for the parties; and (e) the wishes of the parties to a case should be considered. If one or two parties were not interested in hearing the opinion of the ECJ, this was not recommendable (see Craig 1998: 205).

9 The panel data set is unbalanced owing to the inclusion of countries entering the EC at different times.

10 It is important to check for the possible presence of correlation between the unobserved national effects and the explanatory variables included in the panel model, since the presence of correlated heterogeneity invalidates the estimates under the random-effects model. The Hausman specification test, with a $p$-value of .90 , clearly rejects any systematic difference between the coefficients estimated under random effects and the coefficients estimated with fixed effects.

\section{References}

Alter, Karen J. (2000) 'The European Union's Legal System and Domestic Policy: Spillover or Backlash?', International Organizations 54(3): 489-518. 
Alter, Karen J. (2001) Establishing the Supremacy of European Law. The Making of an International Rule of Law in Europe. Oxford University Press.

Alter, Karen. J. and Jeannette Vargas (2000) 'Explaining Variation in the Use of European Litigation Strategies', Comparative Political Studies 33(4): 452-82.

Bai, Jushan and Pierre Perron (1998) 'Estimating and Testing Linear Models with Multiple Structural Changes', Econometrica 66: 47-78.

Bribosia, Herve (1998) 'Report on Belgium', in Anne-Marie Slaughter, Alec Stone Sweet and Joseph H.H. Weiler (eds) The European Court and National Courts Doctrine and Jurisprudence. Oxford: Hart Publishing.

Chalmers, Damian (2001) 'The Positioning of EU Judicial Politics within the United Kingdom', in Klaus H. Goetz and Simon Hix (eds) Europeanised Politics. European Integration and National Political Systems, pp. 169-211. London: Frank Cass Publishers.

Christensen, Jens Peter (2003) Domstolene - den tredje statsmagt. Aarhus: Magtudredningen.

Claes, Monica and Bruno De Witte (1998) 'Report on the Netherlands', in AnneMarie Slaughter, Alec Stone Sweet and Joseph H.H. Weiler (eds) The European Court and National Courts - Doctrine and Jurisprudence, pp. 171-94. Oxford: Hart Publishing.

Conant, Lisa (2001) 'Europeanization and the Courts: Variable Patterns of Adaptation among National Judiciaries', in Maria G. Cowles, James Caposaso and Thomas Risse (eds) Transforming Europe - Europeanization and Domestic Change, pp. 97-116. Ithaca, NY, and London: Cornell University Press.

Craig, Paul P. (1998) 'Report on United Kingdom', in Anne-Marie Slaughter, Alec Stone Sweet and Joseph H.H. Weiler (eds) The European Court and National Courts - Doctrine and Jurisprudence. Oxford: Hart Publishing.

Dolado, Juan J. and Helmut Lütkepohl (1996) 'Making Wald Tests Work for Cointegrated VAR Systems', Econometric Reviews 15: 369-86.

Dworkin, Ronald (1996) Freedoms Law: The Moral Reading of the American Constitution. Oxford: Oxford University Press.

Fligstein, Neil and Alec Stone Sweet (2002) 'Constructing Polities and Markets: An Institutionalist Account of European Integration', American Journal of Sociology 107(5): 1206-43.

Føllesdal, Andreas (2002) 'Rawls in the Nordic Countries', European Journal of Political Theory 1(2): 181-98.

Freeman, Samuel (1990) 'Constitutional Democracy and the Legitimacy of Judicial Review', Law and Philosophy 9: 327-70.

Ginsburg, Tom (2003) Judicial Review in New Democracies. Cambridge: Cambridge University Press.

Golub, Jonathan (1996a) 'Modelling Judicial Dialogue in the European Community: The Quantitative Basis of Preliminary References to the ECJ', EUI Working Paper RSC, No. 96/58: 1-30.

Golub, Jonathan (1996b) 'The Politics of Judicial Discretion: Rethinking the Interaction between National Courts and the European Court of Justice', West European Politics 19(2): 360-85.

Granger, Clive W.J. (1969) ‘nvestigating Causal Relations by Econometric Models and Cross-Spectral Methods', Econometrica 37: 424-38. 
Holtz-Eakin, Douglas, Whitney K. Newey and Harvey S. Rosen (1985) 'Implementing Causality Tests with Panel Data, with an Example from Local Public Finance', NBER Technical Paper Series, No. 48.

Kenny, Sally, William M. Reisinger and John C. Reitz (eds) (1999) Constitutional Dialogues in Comparative Perspective. London: Macmillan.

Lütkepohl, Helmut (1991) Introduction to Multiple Time Series Analysis. Berlin: Springer-Verlag.

Magalhães, Pedro C. (1999) 'The Politics of Judicial Reform in Eastern Europe', Comparative Politics 32(1): 43-62.

Martinsen, Dorte S. (2005) 'The Europeanisation of Welfare - The Domestic Impact of Intra-European Social Security', Journal of Common Market Studies 43(5): 1003-30.

Martinsen, Dorte S. and Karsten Vrangbæk (2008) 'The Europeanization of Health Care Governance: Implementing the Market Imperatives of Europe', Public Administration 86(1): 169-85.

Mattli, William and Anne-Marie Slaughter (1998) 'Revisiting the European Court of Justice', International Organization 52(1): 253-76.

Nergelius, Joakim (2001) 'North and South: Can the Nordic States and the European Continent Find Each Other in the Constitutional Area - or Are They Too Different?', in M. Scheinin (ed.) The Welfare State and Constitutionalism in the Nordic Countries, pp. 79-95. Copenhagen: Nord.

$\mathrm{Ng}$, Serena and Timothy Vogelsang (2002) 'Analysis of Vector Autoregressions in the Presence of Mean Shifts', Econometric Reviews 21: 353-81.

Norton, Philip (1994) The British Polity. New York: Longman.

Pagh, Peter (2004) 'Præjudicielle forelæggelser og Juridisk Specialudvalg', Ugeskrift for Retsvæsen 41: 305-13.

Pitarakis, Jean-Yves and George Tridimas (2003) 'Joint Dynamics of Legal and Economic Integration in the European Union', European Journal of Law and Economics 16: 357-68.

Scheinin, Martin (2001) The Welfare State and Constitutionalism in the Nordic Countries. Copenhagen: Nord.

Shapiro, Martin (1999) 'The Success of Judicial Review', in Sally Kenny, William M. Reisinger and John C. Reitz (eds) Constitutional Dialogues in Comparative Perspective. London: Macmillan.

Shapiro, Martin and Alec Stone (eds) (1994) 'Special Issue: The New Constitutional Politics of Europe', Comparative Political Studies 26(4): 397-561.

Sheive, Sarah W. (1995) 'Central and Eastern Europe Constitutional Courts and the Anti-Majoritarian Objection to Judicial Review', Law and Policy in International Business, June: 1-25.

Stone Sweet, Alec (1992) The Birth of Judicial Politics in France: The Constitutional Council in Comparative Perspective. New York: Oxford University Press.

Stone Sweet, Alec (1999) 'Constitutional Dialogues: Protecting Rights in France, Germany, Italy and Spain', in Sally Kenny, William M. Reisinger and John C. Reitz (eds) Constitutional Dialogues in Comparative Perspective, pp. 8-42. London: Macmillan.

Stone Sweet, Alec (2002) 'Constitutional Courts and Parliamentary Democracy', West European Politics 25(1): 77-100. 
Stone Sweet, Alec and Thomas L. Brunell (1998) 'Constructing a Supranational Constitution: Dispute Resolution and Governance in the European Community', American Political Science Review 92(1): 63-81.

Stone Sweet, A. and Thomas L. Brunell (2004) 'Constructing a Supranational Constitution', in A. Stone Sweet, The Judicial Construction of Europe. Oxford: Oxford University Press.

Stone Sweet, Alec and Wayne Sandholtz (1998) 'Integration, Supranational Governance, and the Institutionalization of the European Polity', in Alec Stone Sweet and Wayne Sandholtz (eds) European Integration and Supranational Governance, pp. 1-27. Oxford: Oxford University Press.

Tsebelis, Georg and Geoffrey Garrett (2001) 'The Institutional Foundation of Intergovernmentalism and Supranationalism in the European Union', International Organization 55(2): 357-90.

Volcansek, Mary L. (1992) 'Judges, Courts and Policy-Making in Western Europe', West European Politics 15(3): 109-21.

Wind, Marlene (2001) Sovereignty and European Integration: Towards a Post-Hobbesian Order. London and New York: Palgrave.

Wind, Marlene (2009) 'Post-National Citizenship in Europe. The EU as Welfare Rights Generator?', Columbia Journal of European Law 15(2), forthcoming.

\section{About the authors}

Marlene Wind is Associate Professor at the Department of Political Science, University of Copenhagen, DK-1353 Copenhagen K, Denmark.

Fax: +453532 3399

E-mail: mwi@ifs.ku.dk

Dorte Sindbjerg Martinsen is Associate Professor at the Department of Political Science, University of Copenhagen, DK-1353 Copenhagen K, Denmark.

Fax: +453532 3399

E-mail: dm@ifs.ku.dk

Gabriel Pons Rotger is senior researcher at the Danish Institute of Governmental Research (AKF), DK-1602 Copenhagen V, Denmark.

Fax: +4543333401

E-mail: gpr@akf.dk 